\title{
Rebuilding the Libraries of Afghanistan
}

\section{Tuesday, 25 October 2011}

\section{Rebuilding the Libraries of Afghanistan - Report}

\section{Scope:}

This report will outline the work that has taken place, largely in the last 10 years, to reclaim the libraries and literary collections of the country, much of which was destroyed and dispersed during nearly 30 years of war, poverty and political insecurity.

The findings presented in this report identify the personalities, institutions and organizations that have contributed to the rebuilding of Afghan libraries and library infrastructure.

Statistical information that can be found is specifically referenced as a means to quantify how far the rebuilding effort has come.

\section{Historical Background:}

Historically libraries in Afghanistan were institutions created by the elite to preserve large collections of religious texts. It was only as late as the 1930's that the concept of libraries as centers of public knowledge and information services took root and every government ministry in the Afghan capital of Kabul had its own library with collections of great importance.

These libraries founded in the 1950's were hard hit by the Soviet occupation and the subsequent warfare in the years leading to the rise of the Taliban regime in 1996. Under the Taliban regime 15 of Kabul's 18 libraries were closed. In some cities all library books were destroyed.

About 80,000 books were lost in the course of Afghanistan's civil war under Taliban rule. Many became sources of heat to fuel stoves during times when wood was scarce, or sold in bazaars at bulk weight to make bags used by shopkeepers to wrap food.

In 2002 it was reported that although the National Library of Afghanistan was still standing its contents had been plundered.

In an article by Abdul Rahin former director of the Kabul University library he explains that although this library served the university, it was also the National Library of Afghanistan and this indicates that they were one and the same library.

A UNESCO report titled Library Development dated 1977 is a detailed account of some 58 pages on the condition of libraries prior to the destruction and can be consulted for information on early statistics.

\section{Major Institutions, Organisations and Personalities}

Nancy Hatch Dupree and the Afghanistan Centre at Kabul University.

Nancy Hatch Dupree, writer, historian and internationally recognized expert on the country, first traveled to Afghanistan in the 1960's. After several decades of living there with her late husband anthropologist and archaeologist Louis Dupree the couple fled to Peshawar after the Soviet invasion of 1979. Here the Duprees established a resource centre for aid workers and Afghan experts; archiving not only their own material but information from a wide variety of sources on every aspect of this period.

This archive is now housed on Kabul University's campus known as the Afghanistan Centre at Kabul University (ACKU). ACKU is the central depository for information on Afghanistan and contains a large and unique collection of books, documents and films relating to Afghanistan's history, culture and development. The ACKU library is now considered the de facto National Library and a new purpose built centre for the collection is currently under construction.

The Louis and Nancy Hatch Dupree Foundation for the Afghanistan Centre at Kabul University was established in 2007 to help raise awareness and funds for ACKU.

Their motto 'Rebuilding Afghanistan, One Book at a Time' is enabled through the ACKU Boxed Library Extension (ABLE) whereby the Foundation is encouraging literacy for both children and adults - 'one reader, one family, one community at a time.'

ABLE mobile libraries are carried by various means - car, donkeys, trucks and the backs of volunteers, across Afghanistan. To date 196 high school and community libraries have been library may be housed in locations such as 
clinics, schools, mosques and shops. The libraries are managed by local custodians and monitored by ABLE staff by regular visits and updates.

ABLE has established 196 high school and community libraries in 32 of Afghanistan's 34 provinces. In addition, some 1,000 libraries modeled on the ABLE program are now operating across the country, supplied by ABLE to other organizations. In 2008, ABLE prepared 796 mini-libraries for the Partnership for Advancing Community Education for Afghanistan (PACE-A). Currently, ABLE has more than 137,750 books in circulation. The number of readers and beneficiaries exceeds many times that number as family members and others take advantage of the opportunity of having access to reading materials.

To meet the demand of new readers, ABLE works with local authors and illustrators to develop and publish easy-toread, local language books. The subjects of the books offer a window into the current needs of Afghans: popular subjects include such practical areas as basic healthcare (eye and dental care, malaria and tuberculosis prevention and treatment), income generation activities (beekeeping, poultry keeping and bicycle repair), computer skills, home management, and earthquake and environmental safety topics. However, book subjects also include history, politics, literature, folklore, archeology, arts, poetry, and children's stories and games. The titles reflect areas of interest identified by communities and schools, and the popularity of the titles is monitored and recorded. To date, ACKU has published 205 titles of high-quality, easy-to-read books for distribution through the ABLE network.

\section{Atifa Rawan and the University of Arizona Libraries (UAL)}

The University of Arizona has committed itself to working with Afghanistan Higher Education to rebuild Afghanistan academic libraries since 2002. Atifa Rawan, an Afghan-American UAL faculty librarian, has made six trips and has completed extensive library assessment, reports, staff training and digital library development. Rawan is the 2005 recipient of the American Library Association Elizabeth Futas Catalyst for Change Award for her work in Afghanistan and her contributions to US libraries.

The UA in partnership with the ACKU and Nancy Hatch Dupree has collaborated on 'Preserving and Creating Access to Afghanistan Literature' a project that will catalogue, digitise and create metadata for the center's collection covering the period from Jihad period, 1989 to 2006.

Scanning documents at ACKU

The project has 15 staff members in Afghanistan who, with Rawan and UAL colleague Yan Han, are also building a preservation infrastructure at Kabul University that the 19 universities in Afghanistan can eventually use to access the digital information. Dupree serves as the historian on the project checking both the value and validity of the materials.

\section{Afghanistan Digital Library Initiative:}

The UA is also a member of the Digital Library Alliance (DLA) which includes universities around the world and in Afghanistan. The Afghan eQuality Alliances: $21^{\text {st }}$ Century Universities for Afghanistan initiative is funded by the United States Agency for International Development (USAID) and Washington State University.

The aim is to establish a digital library environment including a centralised integrated library system built with open source software. This centralized ILS will initially support four academic universities in Kabul (Kabul University,

$$
\text { Kabul University Central Library }
$$

Polytechnic University, Kabul Medical University and Kabul Education University), with a view to including other regional institutions throughout Afghanistan. Rawan and Han have worked on the project since 2005.

\section{New York University and the Afghanistan Digital Library:}

The Afghanistan Digital Library is a project of New York University Libraries. The project is collecting, cataloging, digitizing, and making available over the Internet as many Afghan publications from the period 1871-1930 as it is possible to identify and locate.

Phase 1 of the project, undertaken in 2005, has drawn materials from the collections of several private collectors as well as from the holdings of New York University Library and the British Library.

Phase 2, undertaken in 2006, involves training staff at the National Archives in Kabul in conservation, digitization and cataloging of materials held in various public and private collections inside Afghanistan.

\section{American Academic Libraries in Afghanistan and Qatar}

In 2006, supported by USAID, the American University of Afghanistan (AUAF) was established in Kabul.

In 2009 the library had five staff members - only one a professionally trained librarian. The library had implemented $\mathrm{KOHA}$, an open source integrated library system on a server hosted by LibLime which made access to the OPAC, circulation, cataloguing and other modules possible. Resources in the library consist of a mix of donated, downloaded 
and purchased books, serials and reports in print and electronic formats. Much required original cataloguing and the main impediments were the lack of trained staff with no library training opportunities in Afghanistan.

\section{AUAF Library}

Collaboration has existed between AUAF and the Texas A \&M University at Qatar to train staff. Reach out to Asia has assisted with a training visit to Qatar. With little or no budget unique solutions have been devised between the participating libraries.

\section{ARoLP and the INLTC Law Library}

The Afghanistan Rule of Law Project (ARoLP) is funded by USAID and aims to develop the justice sector, increase access to justice and public demand for rule of law. In 2008 they opened a new law library at the Independent National Legal Training Center (INLTC). For the first time this meant that Afghanistan's legal community had access to a comprehensive collection of Afghan, foreign, and international laws. Eventually, the library will house more than 5,000 legal volumes and will become Afghanistan's first depository library where future laws and legal materials will be available and preserved in one place. Ideally the web-based INTLC Law Library catalogue will be online to facilitate national inter-library loan.

\section{Afghanistan Research and Evaluation Unit (AERU)}

ARoLP Library

Since 2002 AERU, an independent research organization has maintained a library of Afghanistan-specific materials to support its own research. In 2003 the Society of South Asian Studies, formerly the British Institute of Afghan Studies (BIAS), agreed to donate an estimated 3,000 library books and off-prints pertaining to Afghanistan and the region to the AREU Library. A condition of the donation was that the collection should remain in Afghanistan and be available for all researchers to use. The BIAS, established in Kabul in 1972, had undertaken a number of archaeological projects and supported British scholars conducting anthropological and ethnological fieldwork. In 1981 the Institute was closed down and the collection put into storage in the British Embassy.

\section{AERU Library}

It was due to the efforts of several people including Carla Grissmann that this donation was made to the AERU. The late Carla Grissmann was a central figure in the study and protection of Afghanistan's cultural heritage and is also acknowledged on the ACKU's website.

With financial support from the United Nations Assistance Mission in Afghanistan (UNAMA) AREU has re-housed the collection, provided staff to catalogue it with funds to expand the holdings.

The growing collection now includes Afghan government publications from all periods as well as donor and NGO materials published about Afghanistan, relevant publications from UN agencies, periodicals, maps, CDs and DVDs.

The AREU library's main aim is not to compete with international collections, but rather to gather and preserve relevant materials available both within Afghanistan and abroad for use by national and international researchers. AREU's library has over 13,000 titles, and is fully searchable online.

\section{Public Libraries}

Before the civil wars there were six libraries in the capital city of Kabul and six provincial libraries. Three of the six libraries in Kabul were completely destroyed and their collections dispersed. All six provincial libraries were damaged. In recent years the Department of Public Libraries has not only re-established its modest pre-war network of 32 but has also succeeded in opening many other new libraries, both in Kabul and around the country. There are now 10 branch libraries in Kabul (including Afghanistan's only prison library at Pul-e-Charkhi Prison) and a further 50 provincial library branches. Kabul Public library also has a mobile library van which services 12 outlying districts of Kabul.

Kabul Public Library has a total of approximately 200,000 books, with around 50 per cent in Dari, 30 per cent in Pashtu and 20 per cent in English, plus smaller numbers of books in Russian, French and other languages.

The small Children's Library houses over 2,500 books donated by the Goethe-Institute, mainly in German but with some Dari and Pashtu translations of German books and a few English publications. The Goethe-Institute has also donated children's tapes and videos but the library currently lacks the equipment to watch them.

\section{Kabul Public Library}

The Library uses the Dewey decimal system. A few years ago Dutch consultants introduced a computer cataloguing system and trained the staff in how to use it. Apparently some 80 per cent of the Library's holdings were successfully computerised but then the funding ran out and the system was abandoned in favour of the old manual catalogue card system. 
An Internet cafe was set up at the Library in 2003 with UNESCO funding but six months later The Ministry of Information and Culture changed the law and it was entrusted to a private operator, subsequently ceased operations and has since been shut. The Library's management is currently looking for a way to restore it. In the meantime the Director is planning to open a small coffee shop in the Library garden.

The Library's main problem is lack of funds to improve its operations. The collection has already grown far too big for the building and many works are stacked in piles on the floor due to lack of storage space. The building itself is in need of repair and with no climate control the condition of many of the books and other documents is deteriorating. There is particular concern for the fate of the valuable historic newspaper collection which is urgently in need of a more secure and controlled environment.

Since there are currently no librarianship training courses on offer in Afghanistan, most employees are trained inhouse, although some staff members have taken short training courses in Iran.

\section{Conclusion}

Afghanistan had a network of public libraries in major cities until the early 1990s. While efforts are now being made to restore infrastructure and collections across the country, quality remains patchy and access very limited.

Since 2001 the Ministry of Information and Culture's Department of Public Libraries has engaged in rebuilding the public library infrastructure in Afghanistan. Fortunately, the Kabul Public Library seems to have suffered relatively little looting during the conflict of 1993-4, and its collection remained largely intact.

Between 2001 and 2006 all 32 provincial public libraries were reportedly reopened, along with the inauguration of new libraries in Ghazni (2001), Daykundi (2004), and Nuristan, Parwan (Siya Gerd) and Panjshir (2006).

Nonetheless, with the exception of Kabul, Herat, Mazar-e-Sharif (Balkh) and a few eastern provinces, library provision in Afghanistan remains poor, with very few suitable books available to the public and donations hindered by the poor security situation.

University libraries also suffered badly during the 1990s, but whilst those in Kabul, Herat and Mazar-e-Sharif have since received donations of modern text books in English and in local languages, universities in other less secure regions have yet to rebuild their collections.

Since 2001 the Délégation archéologique Française en Afghanistan (DAFA) Library, the Afghan Institute of Archaeology Library and the Academy of Sciences Library have reopened and two new research libraries have been established.

The Afghanistan Centre at Kabul University (ACKU) makes available valuable Afghanistan collections assembled during the war years in neighbouring Pakistan, while the Afghanistan Research and Evaluation Unit (AREU) has taken over the former British Institute of Afghan Studies (BIAS) library of books and offprints pertaining to Afghanistan and the region. Both these libraries are now attempting to collect contemporary scholarship on Afghanistan.

\section{Ongoing Issues}

One of the biggest problems facing the Afghan library sector is the serious shortage of teaching and research material in Pashtu. This problem predates the civil conflicts of the 1990s - while strong in literature, Pashtu has always been less strong in technical materials, and although efforts are now being made to redress the situation, the Ministry of Information and Culture reports that for every eight new books in Dari only two new books can be acquired in Pashtu. Many book donations have been received from Iran, and technical books published in Farsi may now be found widely in many Afghan libraries, although there is debate about the content of some of this material, in terms of political and cultural history.

Conservation is an ongoing issue, with Afghan librarians struggling to provide access for users, while at the same time protecting material from damage due to over-use, neglect and climate conditions. There is an urgent need for practical training in the preservation of library materials through low-cost techniques that can be undertaken by the staff themselves, where appropriate.

Another recurring problem is that of inappropriate donations, which are often made without consultation with local librarians, and result in piles of books lying unused on library shelves or stacked up in library storerooms and corridors.

\section{Training of librarians}

No professional training courses in librarianship are offered in Afghanistan, and few of the staff working in Afghanistan's libraries have benefited from training in librarianship abroad. Librarianship in Afghanistan is not considered a skilled profession; library staff all over the country are generally recruited from other fields and the focus during recruitment tends to be on the janitorial aspects of their duties. Staff also tend to be moved on after a very short time, and therefore do not have the chance to develop their skills. 
As in many developing countries, the priority for most Afghan librarians at this point in time is simply to be able to organise and manage books and documents efficiently and serve their clientele with a minimum of materials and technology.

In the absence of any formal librarianship training programmes, this has been the core aim of the short training courses in librarianship offered in recent years through the auspices of the Afghanistan Research and Evaluation Unit (AREU) Library and the Afghanistan Centre at Kabul University (ACKU).

In 2008 UNESCO sponsored AREU and ACKU to carry out a three-month training programme for university librarians, followed by a two-month training programme for librarians from the Ministry of Information and Culture, and finally by a third stage involving a survey of all provincial libraries and their needs. The Asia Foundation then gave funding for the training of provincial library staff in Herat, Mazar-e-Sharif and Jalalabad, both on-site and at

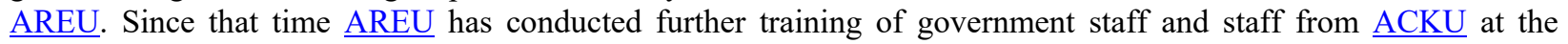
University of Kabul Central Library. Other small training sessions have been organised by the French Embassy, GTZ and the Goethe-Institut.

The Ministry of Information and Culture's Department of Public Libraries is keen to identify international partnerships which will facilitate the development of further basic training programmes for Afghan librarians.

\section{References}

250mercer 2011, Nancy Hatch Dupree on why she has devoted her life to the Afghan people, 29 April, viewed 14

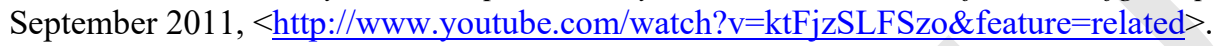
250mercer 2011, Afghanistan Centre at Kabul University: building a school library, 8 January, viewed 14 September 2011, <http://www.youtube.com/watch? $\mathrm{v}=\mathrm{rD}$ nid3D0rw $>$.

Boone, J 2009, 'A librarian's labour of love for Afghanistan', The Financial Times, 14 February, viewed 7 September 2011, <http://www.ft.com/cms/s/2/45a7ebca-f712-11dd-8a1f-0000779fd2ac.html\#axzz1VI3lenVe $>$. ABLE (ACKU boxed library extension) 2011, Louis and Nancy Hatch Dupree Foundation, viewed 7 September 2011, < http://www.dupreefoundation.org/able.htm>.

Erickson, CA 2010, ‘Able in Afghanistan', American Libraries, vol. 41, no. 1/2, pp. 44-47, Health Source: Nursing/Academic Edition, EBSCOhost, viewed 7 September 2011.

Garner, A 2007, 'Rebuilding Afghanistan ... one book at a time', American Libraries, vol. 38, no. 10, pp. 52-54, Health Source: Nursing/Academic Edition, EBSCOhost, viewed 14 September 2011.

Kniffel, L 2002, Afghanistan Reports reveal Devastated Libraries, American Libraries, vol. 33, no. 3 pp. 22 -23, Health Source: Nursing/Academic Edition, EBSCOhost, viewed 25 September 2011.

Garner, A 2007, 'Rebuilding Afghanistan ... one book at a time', American Libraries, vol. 38, no. 10, pp. 52-54, Health Source: Nursing/Academic Edition, EBSCOhost, viewed 14 September 2011.

Rahin, AR 1998, The situation of Kabul University Library: its past and present, World Libraries, viewed 27 September 2011, <http://www.worlib.org/vol08no2/rahinv8n2.shtml >.

2008, 'Scanning Afghan Documents at the ACKU' [image] in stepnout's photostream, Flickr, viewed 12 September 2011, < http://www.flickr.com/photos/stepnout/2983333882/in/photostream/>.

Han, Y and Rawan, A 2007, 'Afghanistan digital initiative: revitalizing an integrated library system', Information Technology \& Libraries, vol. 26 no. 4, pp. 44-46, Academic Search Complete, EBSCOhost, viewed 7 September 2011.

Han, Y 2010, 'The road to digital: building unique Afghanistan collections', OCLC Systems \& Services: International digital library perspectives, vol. 26 no. 1, pp. 46-57, Emerald, EBSCOhost, viewed 15 September 2011.

Everett-Haynes, LM 2008, Librarian leading UA effort to build Afghanistan's libraries, University Communications, University of Arizona, viewed 7 September 2011, < http://uanews.org/node/19718>.

Afghanistan Digital Library 2005, About Afghanistan digital library, New York University, viewed 15 September 2011, < http://afghanistandl.nyu.edu/about.html $>$.

Malden, C 2005, Atifa Rawan named Futas winner, American Library Association, viewed 7 September 2011, $<$ http://www.ala.org/Template.cfm?Section=News\&template=/ContentManagement/ContentDisplay.cfm\&ContentI $\mathrm{D}=90940>$.

NYU Digital Library Technology, Projects, New York University, viewed 15 September $2011<$ http://dlib.nyu.edu/dlts/projects/>.

2008, 'Kabul University Central Library' [image] in stepnout's photostream, Flickr, viewed 15 September 2011, $<$ http://www.flickr.com/photos/stepnout/2981246389/in/photostream/>. 
USAID/Afghanistan 2008, Afghanistan's first full-service law library opened, USAID, viewed 16 September 2011, $<$ http://afghanistan.usaid.gov/en/USAID/Article/386/Afghanistans First FullService Law Library Opened $>$. USAID/Afghanistan 2008, Independent National Legal Training Center law library membership surpasses 200 in first month, USAID, viewed 16 September 2011,

$<$ http://afghanistan.usaid.gov/en/USAID/Article/420/Independent_National_Legal_Training_Center_Law_Library Membership_Surpasses 200_In_First Month>.

Checchi and Company Consulting, Inc 2008, Sixteenth Quarter Performance Monitoring Report 2008, USAID, viewed 16 September 2011, <http://pdf.usaid.gov/pdf_docs/PDACM740.pdf.>.

Thompson, C , Frouzen, Z, Malone, J, Esfahani, B \& Hanson, M 2010, 'Assistance across Borders: American Academic Libraries in Afghanistan and Qatar', Collaborative Librarianship 2010, vol. 2 no. 2, pp. 86-95, viewed 7 September 2011, <http://collaborativelibrarianship.org/index.php/jocl/article/view/74/52>.

Leslie, J 2011, Carla Grissman 1928-2011, ACKU, viewed 17 September 2011,

$<$ http://www.acku.edu.af/?p=News $>$.

2008, 'ARoLP Library' [image] in stepnout's photostream, Flickr, viewed 17 September 2011, $<$ http://www.flickr.com/photos/stepnout/2987355140/in/photostream/>.

2008, 'AERU in Kabul' [image] in stepnout's photosteam, Flickr, viewed 17 September 2011, $<$ http://www.flickr.com/photos/stepnout/2981246355/in/photostream/>.

Visiting Arts 2011, Libraries, Afghanistan Cultural Profiles, viewed 18 October 2011,

$<$ http://www.afghanistan.culturalprofiles.net/?id=-1053 >.

Visiting Arts 2011, Kabul Public Library, Afghanistan Cultural Profiles, viewed 18 October 2011,

$<$ http://www.afghanistan.culturalprofiles.net/?id=35>.

Mitchell, C 2008, 'Kabul Public Library' [image] in Carol Mitchell's photostream, Flickr, viewed 18 October 2011, $<$ http://www.flickr.com/photos/webethere/2538639884/>.

New York Public Library 2009, 'Librarian Sarah Ziebell on location in Afghanistan' 22 December, viewed 17

September 2011, <http://youtu.be/h0FfBd0d9Aw>.

Eyre, J 1977, Republic of Afghanistan: library development (NATIS), report prepared for the Government of the Republic of Afghanistan by the United Nations Educational, Scientific and Cultural Organization (UNESCO), viewed16 October 2011, < http://unesdoc.unesco.org/images/0002/000243/024341eo.pdf $>$.

U.S. Embassy Kabul Afghanistan 2010, 'American University of Afghanistan' [image] in U.S. Embassy Kabul Afghanistan's photostream, Flickr, viewed 25 October 2011, $<$ http://www.flickr.com/photos/kabulpublicdiplomacy/5016830170/in/photostream/>. 